\title{
THE 2011 LOCAL ELECTIONS: BERLUSCONI LOST, BUT WHO WON?
}

\author{
Guido Legnante
}

With the double defeat of the center-right in Milan and Naples, the local elections on 15-16 and 29-30 May 2011 marked a turning point in Italian politics. In Milan, the "moral capital" and center of Silvio Berlusconi's empire, the outgoing mayor, Letizia Moratti, was defeated by the center-left candidate Giuliano Pisapia in an outcome that recalled, with the roles reversed, the historic defeat of the center-left in Bologna in 1999. In Naples, the city that symbolizes the difficulties faced by the center-left in government, the center-right candidate Giovanni Lettieri was incapable of offering an alternative and lost to the outsider, Luigi de Magistris, an ex-magistrate and a member of Italia dei Valori (IdV, Italy of Values) who, in the first round, had beaten Mario Morcone, the candidate representing the Partito Democratico (PD, Democratic Party) and Sinistra Ecologia e Libertà (SEL, Left Ecology and Freedom).

This historic vote evoked the first election of direct mayors in 1993 in some respects, coming as it did after fundamental changes in the political offer. In 1993, the parties and voters had moved out of the proportional system and the stability of the First Republic into the majority-based system of the Second Republic. ${ }^{1}$ The 2011 election featured a "third pole" that was no longer permanently allied with the center-right. Its aim was to hold the balance of power in a new phase of change. The political offer was also characterized by candidates and parties of a populist nature who succeeded in gaining votes at 
the expense of longer-established parties and, in particular, of those in national government. Even though, as we shall see in this chapter, the local elections inevitably created a complicated mosaic, the headlines in the government-leaning newspapers on 31 May were very clear: "The Heart of Berlusconism Is Struck" (Il Foglio), "Second Round Brings a Bashing from the Madonnina" (La Padania), "A Blow for Silvio" (Libero), "Election Disaster: A Perfect Suicide" (Libero Milano). Surprisingly, it was the Gazzetta dello Sport-a paper with an extremely wide circulation but a target readership that is often unaware of political issues-whose headline provided the most effective summing up of the outcome of the elections: "Berlusconi Has Lost: But Who Is the Real Winner of These Elections?"

It is difficult (and beyond the scope of this chapter) to say whether and how the results of these elections impacted on the increasing difficulties that Berlusconi's government went on to experience in the summer of 2011. Certainly, the spring vote carried some weight in national politics, revealing the weakness of the center-right in the first round and issuing a number of key defeats in the second. However, attempting to interpret the outcome of the local elections against the national background does not help us to reflect on the factors that lay behind it. These elements can be understood only by exploring in some depth what actually took place in the cities. The first part of this chapter will analyze the opinion climate and the characteristics of the political offer in the May vote, while the second will examine data concerning the turnout and the votes cast. The third section will focus on Milan and Naples, whose results attracted the most attention in post-election analyses; however, these cities were different as regards the candidate selection, campaigns, and voting behavior. The final section will discuss the overall findings of the chapter and reconsider the 2011 local elections from the perspective of a future general election.

\section{A Changing Political Offer}

As well as being a selection process for the governing class, local elections count because they provide indications regarding the popularity of political parties. These results can be viewed alongside those from opinion polls and thus help to evaluate the climate of public opinion within which national political competition takes place. ${ }^{3}$ In this respect, their timing compared with general elections and other national elections is decisive. The general elections of 2001 and 2006 had each been preceded by regional elections the year before and by the European 
Parliament elections two years earlier. The early dissolution of Parliament after the fall of the Prodi government and the 2008 general election, on the other hand, inverted the electoral cycle. As a result, the next scheduled major elections in Italy will take place in 2013, that is, several years after the European and regional elections of 2009 and 2010. Hence, in the intervening period between 2010 and 2013, only the local elections can give an indication (beyond opinion polls, of course) of the health of the political parties, placed, as they surely will be, even more under the spotlight in the event of unexpected and sensational results.

There are two main elements of local elections that tend to catch the attention of observers: first, the presence of big cities, which may have symbolic value for the parties involved, and, second, the large number of citizens being called to vote, especially if they are seen as representative of the entire electorate, thus enabling the local elections to be depicted as a test of national opinion. The 2011 vote fully met the first of these criteria and largely met the second. In addition to Milan and Naples, the elections featured five other regional capitals (Turin, Trieste, Bologna, Catanzaro, and Cagliari), 24 provincial capitals, ${ }^{4}$ and 102 other cities with over 15,000 inhabitants (in total, 133 such councils were therefore up for election). Although the total of eligible voters was just over 10 million, the demographic importance of the councils being elected gave a fair reflection of the ratios across the various parts of the country. For example, in a comparison with the 118 councils that had also voted in the 2010 regional elections, Roberto D'Alimonte estimated that 40 percent of the voters were in the North, 17 percent in the Center, and 44 percent in the South. These shares almost perfectly overlap with those pertaining to the last general election. ${ }^{5}$

As far as the political offer is concerned, one of the most interesting aspects was the choice of parties that made up the third pole: Futuro e Libertà per l'Italia (FLI, Future and Freedom for Italy) and Unione di Centro (UdC, Union of the Center). In addition, and particularly in the case of the center-left, the elections were a test of the cohesion of traditionally composite coalitions at the local level. If we limit ourselves to the cases where parties were explicitly listed on the ballot papers, ${ }^{6}$ table 4.1 shows that in only eight cases was the electoral offer similar to the national one for all of the main coalitions. In the others, various factors contributed to a different competitive structure from the tripolar one found (at least at the time of writing) at the national level: an alliance of the UdC (especially in many of the major southern cities) and/or the FLI with the center-right (and in two cases an alliance of the UdC and the center-left), or the defection of the IdV and/or the SEL from the center-left alliance, or both of these elements. 
TABLE 4.1 The Political Offer in the Main Cities (population over 15,000) in the 2011 Council Elections

\begin{tabular}{|c|c|c|c|c|c|}
\hline & \multicolumn{4}{|c|}{ Main Center-Left Parties } \\
\hline \multirow{8}{*}{ 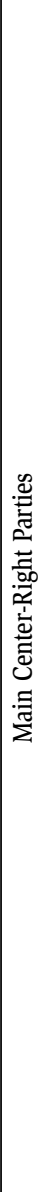 } & & $\begin{array}{l}\text { Political offer } \\
\text { similar to the } \\
\text { national one }\end{array}$ & $\begin{array}{l}\text { IdV and SEL } \\
\text { allied and } \\
\text { opposed to } \\
\text { center-left }\end{array}$ & IdV alone & SEL alone \\
\hline & $\begin{array}{l}\text { Political offer } \\
\text { similar to the } \\
\text { national one }\end{array}$ & $\begin{array}{l}\text { Turin, Milan, } \\
\text { Varese, Bologna, } \\
\text { Arezzo, Siena, } \\
\text { Benevento, } \\
\text { Barletta }\end{array}$ & Pordenone & $\begin{array}{l}\text { Novara, } \\
\text { Naples, } \\
\text { Salerno }\end{array}$ & \\
\hline & $\begin{array}{l}\text { PdL and LN } \\
\text { separate; UdC } \\
\text { and FLI } \\
\text { separate (and } \\
\text { opposed to } \\
\text { center-right) }\end{array}$ & Trieste & & & \\
\hline & $\begin{array}{l}\text { UdC and FLI } \\
\text { separate (and } \\
\text { opposed to } \\
\text { center-right) }\end{array}$ & Ravenna & Rovigo & & Rimini \\
\hline & $\begin{array}{l}\text { UdC and FLI } \\
\text { allied with } \\
\text { center-right }\end{array}$ & Ragusa & & & \\
\hline & $\begin{array}{l}\text { FLI allied with } \\
\text { center-right }\end{array}$ & Fermo & & & \\
\hline & $\begin{array}{l}\text { UdC allied with } \\
\text { center-right }\end{array}$ & $\begin{array}{l}\text { Latina, Caserta, } \\
\text { Catanzaro, } \\
\text { Crotone, } \\
\text { Cagliari, Olbia, } \\
\text { Iglesias }\end{array}$ & $\begin{array}{l}\text { Cosenza, } \\
\text { Reggio Calabria }\end{array}$ & Carbonia & \\
\hline & $\begin{array}{l}\text { UdC allied with } \\
\text { center-left }\end{array}$ & Savona & & & Grosseto \\
\hline
\end{tabular}

Source: Adaptation of data provided by the Ministry of the Interior, Central Election Service. 
What made the local nature of these elections even stronger was the existence of a number of civic lists (including "personal" lists connected with mayoral candidates) and, in 18 of the main cities where voting took place, of Beppe Grillo's Movimento 5 Stelle (M5S, Five Star Movement). As table 4.2 shows, the average number of candidates in the main cities was 7.7, while the average number of lists was 21.3. Compared with the previous elections, in the same cities, the average increases were 2.1 candidates and 1.4 lists. While the figures for the lists confirm the increasing fragmentation of the political offer for city councils during the course of the Second Republic, the increase in the number of candidates represents a new phenomenon, as in previous years it had tended to fall as a result of the formation of broad alliances. Although there were also local factors at play, what these data have in common is the increase in "third" candidacies outside the main center-left and center-right blocs. ${ }^{7}$ This is also confirmed by the number of votes cast for the top two candidates, which fell in 23 of the 30 main cities and, on average, decreased by 8.4 percent, and an almost twofold increase in the votes for third candidates (from 10.6 percent to 19 percent of valid votes).

In local elections, it is usually the political parties in power at the national level that suffer the greatest difficulties. ${ }^{8}$ They lose more councils than they gain because once the "honeymoon" period that follows the election has elapsed (usually within a year), national governments tend to experience a fall in support in the intermediate stage of the legislature and can only try to recover lost ground toward the end of their mandate. It is worth noting here, however, that in the new electoral cycle described earlier, the center-right government had enjoyed a particularly long honeymoon that covered the period of the European Parliament elections in 2009 and the regional ones in $2010 .{ }^{9}$ In the months that accompanied the worsening economic crisis, the formation of the third pole, the exit of some members from the majority, and the personal difficulties of the prime minister had all contributed to a loss of support for the government and a decline in the number of voters it could count on. These events certainly cranked up interest in the 2011 local elections. Moreover, just as we had seen in the middle period of the 2001-2006 legislature, ${ }^{10}$ the drop in support for the Berlusconi government had not seemed to bring a corresponding increase in the popularity of the opposition.

The local elections were preceded by a series of primaries on the center-left. While these had provided an opportunity for candidates to become more visible and for the electorate to be mobilized, they had also raised concerns due to the high level of infighting as well as the outcome of the primaries themselves. On 14 November 2010, 
TABLE 4.2 The City Council Elections of 2011 and 2006 (number of candidates for mayor, number of lists, votes for the top two candidates)

\begin{tabular}{|c|c|c|c|c|c|c|}
\hline City & $\begin{array}{c}\text { No. of } \\
\text { candidates } \\
\text { for mayor } \\
2011\end{array}$ & $\begin{array}{c}\text { No. of } \\
\text { candidates } \\
\text { for mayor } \\
2011 \text { vs. } \\
2006\end{array}$ & $\begin{array}{l}\text { No. of } \\
\text { lists } \\
2011\end{array}$ & $\begin{array}{l}\text { No. of } \\
\text { lists } \\
2011 \text { vs. } \\
2006\end{array}$ & $\begin{array}{c}\text { Top two } \\
\text { candidates } \\
\text { ( } \% \text { total } \\
\text { valid votes) } \\
2011\end{array}$ & $\begin{array}{c}\text { Top two } \\
\text { candidates } \\
\text { ( } \% \text { total } \\
\text { valid votes) } \\
2011 \text { vs. } 2006\end{array}$ \\
\hline Novara & 8 & +3 & 15 & -2 & 77.1 & -19.0 \\
\hline Torino & 11 & +2 & 36 & -1 & 84.0 & -12.1 \\
\hline Milan & 9 & -1 & 29 & -5 & 89.6 & -9.4 \\
\hline Varese & 10 & +5 & 18 & +3 & 79.6 & -14.1 \\
\hline Rovigo & 10 & +3 & 26 & +7 & 69.3 & -16.5 \\
\hline Pordenone $^{a}$ & 6 & +2 & 14 & 0 & 76.2 & -19.0 \\
\hline Trieste $^{a}$ & 10 & +2 & 22 & -3 & 68.2 & -28.7 \\
\hline Savona & 7 & +3 & 17 & -1 & 84.2 & -7.2 \\
\hline Bologna ${ }^{a}$ & 9 & -4 & 17 & -6 & 80.8 & +2.3 \\
\hline Ravenna & 6 & 0 & 15 & +1 & 76.5 & -14.5 \\
\hline Rimini & 12 & +6 & 21 & +5 & 72.7 & -18.6 \\
\hline Arezzo & 9 & +5 & 16 & +2 & 77.6 & -21.4 \\
\hline Grosseto & 6 & -1 & 15 & -1 & 81.2 & -7.8 \\
\hline Siena & 5 & 0 & 15 & -2 & 72.9 & -13.0 \\
\hline Fermo & 6 & +4 & 20 & +7 & 78.0 & -22.0 \\
\hline Latina $^{a}$ & 13 & +5 & 26 & +2 & 86.5 & +14.2 \\
\hline Benevento & 4 & +1 & 22 & +7 & 82.6 & -15.9 \\
\hline Caserta & 6 & +3 & 25 & +8 & 78.8 & +6.1 \\
\hline Naples & 10 & +3 & 31 & +5 & 66.0 & -28.8 \\
\hline Salerno & 6 & +2 & 19 & +3 & 91.9 & +12.5 \\
\hline Barletta & 10 & +6 & 25 & +5 & 86.8 & -4.2 \\
\hline Catanzaro & 7 & +2 & 23 & 0 & 94.6 & 23.8 \\
\hline Cosenza & 7 & +3 & 33 & +14 & 72.5 & -11.1 \\
\hline Reggio Calabria $^{a}$ & 6 & +1 & 25 & -11 & 85.0 & -10.8 \\
\hline Crotone & 9 & +6 & 27 & +7 & 56.1 & -42.6 \\
\hline Ragusa & 3 & -4 & 17 & -3 & 93.5 & +12.8 \\
\hline Cagliari & 9 & +3 & 31 & +6 & 89.8 & -2.5 \\
\hline Carbonia & 7 & +2 & 14 & +1 & 85.1 & -4.2 \\
\hline Iglesias $^{a}$ & 3 & -2 & 7 & -6 & 96.0 & +21.6 \\
\hline Olbia $^{a}$ & 6 & +3 & 18 & +1 & 95.6 & -2.2 \\
\hline Average & 7.7 & +2.1 & 21.3 & +1.4 & 81.0 & -8.4 \\
\hline
\end{tabular}

${ }^{a}$ The previous city council elections were held in Pordenone and Trieste on 9-10 April 2006 (alongside the general election); in Latina, Reggio Calabria, and Olbia in 2007; in Bologna in 2009; and in Iglesias in 2010.

Source: Adaptation of data provided by the Ministry of the Interior, Central Election Service. 
the coalition primaries for the Milan mayoral election had seen Pisapia, the candidate representing the SEL, gain a narrow victory over Stefano Boeri, who was mainly supported by the PD (Pisapia won with 45.4 percent to Boeri's 40.2 percent). The drop in turnout from around 82,000 voters in the 2006 Milan primaries to around 67,000 had provoked strong criticisms of the PD, which had proved incapable of mobilizing its voters. The Bologna primaries were held on 23 January 2011, and the PD's candidate, Virginio Merola, had succeeded in holding firm against the strong personal success of Amelia Frascaroli, a candidate from Catholic civil society ( 58.3 percent to 36 percent). In the Naples primaries, Andrea Cozzolino had seen off Umberto Ranieri in a battle between two PD members. In both Bologna and Naples, there had been a greater turnout than in the previous primaries. In Naples, however, this was due to an extraordinarily high turnout in areas strongly influenced by political patronage. This led to a number of appeals that, a few days later, convinced the PD to declare the result invalid. The following week, the Cagliari primaries for the coalition had produced a similar outcome to the one in Milan, with the SEL candidate, Massimo Zedda, overcoming the candidate supported by the PD, Antonello Cabras (46.6 percent to 34.1 percent). Finally, in Turin, on 27 February, the ex-minister from the PD, Piero Fassino, helped by a very high turnout, had swept to victory over his younger party colleague Davide Gariglio (55.3 percent to 27.4 percent).

Just six weeks before the elections, the polls were showing the center-left ahead in Turin and in Bologna and the center-right ahead in Naples, Trieste, Cagliari, and Catanzaro, while in Milan the outcome looked rather uncertain. A month later, in the last poll results to be published, it appeared that the split in the center-right between a candidate of the Popolo della Libertà (PdL, People of Liberty) and one of the Lega Nord (LN, Northern League) in Trieste and the growing popularity of de Magistris in Naples were improving the opposition's prospects. ${ }^{11}$ They also seemed to confirm the probability of a second ballot in Milan and the strengthening of Pisapia's position as the candidate favored by large sections of the moderate electorate.

All in all, at least in terms of how it was covered in the media, the election campaign was played out more at the level of national than local politics. While only the attack made by Moratti against Pisapia (to be discussed later in this chapter) during the closing debate of the campaign had brought the two local candidates onto the center stage of national politics, between the first and second round it had been Berlusconi who had underlined the national significance of the contest on the evening of 20 May, with six very similar interviews given to the radio program GR1 and the television news programs TG1, TG2, TG4, 
TG5, and Studio Aperto. In these, he stated that he was "still on the pitch" and listed the dangers for the Milanese and Neapolitans if they were to elect Pisapia and de Magistris. He also urged anyone who had abstained in the first round to turn out to vote in the second.

\section{An Overview of the Results}

Let us now examine the main outcomes of the May elections. Just as in 2011, as table 4.3 shows, turnout fell (on average it was 2.4 percent down in the main cities). This overall figure, however, hides a marked variability, which shows an increase in some cases (Cagliari +3.9, Iglesias +3.4 , Rimini +2.2 , Turin +1.8 ), an unexpected stability in others (including Milan, with +0.1 ), and a fall in others (Naples -6.4 , Reggio Calabria -7.5 , Bologna -5.0$)$. Turnout declined particularly sharply in Pordenone (-12.2) and Trieste (-18.2), where the previous local elections in 2008 had coincided with that year's general election.

Given the multipolar structure of the political offer, the first round proved decisive only in just over half of the city council elections (table 4.4). Of the 20 provincial capital cities it had previously governed, in the first round the center-left retained control in 10 (Turin, Bologna, Savona, Ravenna, Arezzo, Sienna, Benevento, Salerno, Barletta, and Carbonia); it lost control in 2 (Caserta and Catanzaro); and in the other 8 a second round was required. Of the 10 provincial capital cities it had previously governed, the center-right held control only in 3 (Latina, Reggio Calabria, and Ragusa) in the first round; it lost control of 2 (Fermo and Olbia); ;2 and the remaining 5 went to a second round. Thus, the overall picture shows the center-left better able to maintain its control of councils, including Turin and Bologna, both of which are large cities in which an outright win was not a foregone conclusion. Moreover, the center-left also proved able to gain control of councils in the North that had previously been governed by the center-right. However, particularly in the South, the center-left's position after the first round was less clear.

Once the results of the second round came in, however, the center-left could claim a more straightforward success. It held Naples (even though it was an atypical center-left coalition, i.e., without the PD), Pordenone, Rimini, Grosseto, and Crotone, while it lost Rovigo, Cosenza, and Iglesias. The center-right, on the other hand, only succeeded in holding on to the council in Varese, while it lost in Novara, Trieste, Cagliari, and, most notably, in Milan. Altogether, therefore, the center-left held 15 of the 20 provincial capital cities that it governed before the elections, and lost 5, while gaining 6 from the center-right. 
TABLE 4.3 The City Council Elections of 2011 and 2006 (turnout in first and second rounds, percentage of votes just for mayor)

\begin{tabular}{|c|c|c|c|c|c|c|c|}
\hline City & $\begin{array}{c}\% \\
\text { turnout } \\
2011\end{array}$ & $\begin{array}{c}\text { Diff. in } \\
\text { turnout } \\
\text { (percent. } \\
\text { points) } \\
2011 \text { vs. } \\
2006\end{array}$ & $\begin{array}{c}\% \\
\text { voting } \\
\text { just for } \\
\text { mayor } \\
2011\end{array}$ & $\begin{array}{c}\% \\
\text { voting } \\
\text { just for } \\
\text { mayor } \\
2011 \text { vs. } \\
2006\end{array}$ & $\begin{array}{c}\% \\
\text { turnout } \\
\text { in 2nd } \\
\text { round } \\
2011\end{array}$ & $\begin{array}{l}\text { Diff. in } \\
\text { turnout } \\
\text { 1st \& 2nd } \\
\text { rounds } \\
\text { (percent. } \\
\text { points) } \\
2011\end{array}$ & $\begin{array}{c}\text { Diff. in } \\
\text { turnout } \\
\text { 1st \& 2nd } \\
\text { rounds } \\
\text { (percent. } \\
\text { points) } \\
2006\end{array}$ \\
\hline Novara & 69.0 & -0.2 & 9.6 & -6.0 & 59.0 & -10.0 & \\
\hline Turin & 66.5 & +1.8 & 11.0 & -8.9 & & & \\
\hline Milan & 67.6 & +0.1 & 9.3 & -3.1 & 67.4 & -0.2 & \\
\hline Varese & 64.1 & -1.3 & 13.0 & -1.4 & 55.5 & -16.4 & \\
\hline Rovigo & 71.0 & -2.5 & 8.5 & -0.2 & 60.0 & -11.0 & -5.2 \\
\hline Pordenone $^{a}$ & 68.6 & -12.2 & 15.1 & +6.1 & 60.4 & -8.1 & \\
\hline Trieste $^{a}$ & 56.7 & -18.2 & 20.5 & +4.7 & 51.6 & -5.1 & \\
\hline Savona & 68.7 & -0.4 & 6.7 & -1.1 & & & \\
\hline Bologna $^{a}$ & 71.4 & -5.0 & 10.1 & +3.9 & & & -14.2 \\
\hline Ravenna & 72.0 & +1.1 & 8.1 & +3.2 & & & \\
\hline Rimini & 67.8 & +2.2 & 13.2 & +4.6 & 61.0 & -6.8 & \\
\hline Arezzo & 72.1 & -2.5 & 14.1 & +1.7 & & & \\
\hline Grosseto & 73.4 & -2.9 & 11.1 & +1.6 & 63.0 & -10.4 & \\
\hline Siena & 76.6 & -1.7 & 6.4 & -1.2 & & & \\
\hline Fermo & 72.0 & -5.4 & 7.8 & +1.5 & & & \\
\hline Latina $^{a}$ & 79.1 & -3.3 & 4.4 & -1.2 & & & \\
\hline Benevento & 83.1 & -2.1 & 3.6 & +1.4 & & & \\
\hline Caserta & 79.2 & -3.1 & 3.5 & +1.7 & & & -15.3 \\
\hline Naples & 60.3 & -6.4 & 12.1 & +5.1 & 50.6 & -9.8 & \\
\hline Salerno & 78.5 & -1.2 & 5.6 & -3.3 & & & -10.1 \\
\hline Barletta & 77.1 & -1.2 & 2.8 & -1.8 & & & \\
\hline Catanzaro & 79.9 & -1.6 & 2.6 & +0.6 & & & -22.7 \\
\hline Cosenza & 73.3 & -3.7 & 2.6 & -1.0 & 55.4 & -17.8 & \\
\hline Reggio Calabria $^{a}$ & 74.5 & -7.5 & 3.3 & 1.3 & & & -18.2 \\
\hline Crotone & 75.4 & -1.8 & 3.2 & 2.5 & 57.0 & -18.4 & \\
\hline Ragusa & 72.0 & -2.0 & 5.1 & -0.9 & & & -15.2 \\
\hline Cagliari & 71.4 & 3.9 & 9.5 & -0.5 & 62.2 & -9.2 & \\
\hline Carbonia & 70.2 & 0.1 & 4.5 & 0.0 & & & \\
\hline Iglesias $^{a}$ & 76.5 & 3.4 & 6.7 & 0.3 & 69.1 & -1.1 & -14.9 \\
\hline Olbia $^{a}$ & 78.8 & 0.5 & 6.6 & 2.6 & & & \\
\hline Average & 72.2 & -2.4 & 8.0 & 0.4 & 59.4 & -9.6 & -14.5 \\
\hline
\end{tabular}

${ }^{a}$ The previous city council elections were held in Pordenone and Trieste on 9-10 April 2006 (alongside the general election); in Latina, Reggio Calabria, and Olbia in 2007; in Bologna in 2009; and in Iglesias in 2010.

Source: Adaptation of data provided by the Ministry of the Interior, Central Election Service. 
TABLE 4.4 Results of the 2011 City Council Elections in 30 Provincial Capital Cities

\begin{tabular}{|c|c|c|c|c|c|c|c|c|}
\hline & & \multicolumn{3}{|c|}{ First Round } & \multicolumn{2}{|c|}{ Second Round } & \multicolumn{2}{|c|}{ Total } \\
\hline Area & $\begin{array}{l}\text { Outgoing } \\
\text { administration }\end{array}$ & Won & Lost & $\begin{array}{l}\text { Went } \\
\text { to } 2 \text { nd } \\
\text { round }\end{array}$ & Won & Lost & Won & Lost \\
\hline \multirow[t]{2}{*}{ North } & Center-left & 2 & 0 & 2 & 1 & 1 & 3 & 1 \\
\hline & Center-right & 0 & 0 & 4 & 1 & 3 & 1 & 3 \\
\hline \multirow[t]{2}{*}{ Red zone } & Center-left & 4 & 0 & 2 & 2 & 0 & 6 & 0 \\
\hline & Center-right & 0 & 1 & 0 & - & - & 0 & 1 \\
\hline \multirow[t]{2}{*}{ South } & Center-left & 4 & 2 & 4 & 2 & 2 & 6 & 4 \\
\hline & Center-right & 3 & 1 & 1 & 0 & 1 & 3 & 2 \\
\hline \multirow[t]{2}{*}{ Total } & Center-left & 10 & 2 & 8 & 5 & 3 & 15 & 5 \\
\hline & Center-right & 3 & 2 & 5 & 1 & 4 & 4 & 6 \\
\hline
\end{tabular}

Source: Adaptation of data provided by the Ministry of the Interior, Central Election Service.

The picture that emerges from the city council elections in provincial capital cities is confirmed on a wider scale by Ilvo Diamanti's study, which looks at all cities with over 15,000 inhabitants and shows that the center-right held on to 19 councils, captured the same number from the center-left, but lost 33, including 17 of the 22 it governed in the North. A less unbalanced picture emerged in the Center-South, with the center-right holding on to approximately half of the councils it ran, and the center-left maintaining control in roughly two-thirds. ${ }^{13}$

As far as support for the political parties is concerned, D'Alimonte's analysis of 118 cities (with over 15,000 inhabitants each) that voted in both the 2011 local and 2010 regional elections shows a number of interesting results, which are summarized in table 4.5. ${ }^{14}$ In Italy as a whole, the two main coalitions lost votes: the center-left declined by 1.2 percentage points (from 44.4 to 43.2 percent) and the center-right slipped 7.5 points (from 45.5 to 38 percent). By contrast, the third pole gained 3.5 points (rising from 6.4 to 9.9 percent). However, this picture varies significantly across the country: in the North, where there was a clear shift from the previous elections, the center-left gained 3.8 percentage points, while the center-right vote dropped by 10.2 percent; in the "red zone" of central and central-northern Italy, the center-left and the third pole remained stable, while the center-right lost 9.9 percent of its share of the votes; in the South, however, both lost ground, with a drop of 5.7 percent in the center-left vote and 4.4 percent in the centerright vote, while the third pole succeeded in increasing its vote by no 
TABLE 4.5 Comparison between Provincial Capital Results in the 2011 City Council Elections and the 2010 Regional Elections (first-round votes)

\begin{tabular}{l|ccc|ccc}
\hline & \multicolumn{3}{c}{ 2011 City Council Elections } & \multicolumn{3}{c}{ Difference with 2010 Regional Results } \\
\hline Area & Center-left & Third pole & Center-right & Center-left & Third pole & Center-right \\
\hline North & 47.1 & 5.3 & 39.2 & +3.8 & +1.9 & -10.2 \\
Red zone & 52.8 & 4.2 & 28.3 & +0.2 & -0.2 & -9.9 \\
South & 36.6 & 15.8 & 40.5 & -5.7 & +6.0 & -4.4 \\
Italy & 43.2 & 9.9 & 38.0 & -1.2 & +3.5 & -7.5 \\
\hline
\end{tabular}

Source: Adaptation of data by R. D’Alimonte, Il Sole 24 Ore, 5 June 2011.

less than 6 percentage points. These variations were also partly a result of the population size of the cities: while the center-right lost across the board, the center-left lost 5.1 percent in cities with a population of between 15,000 and 50,000 inhabitants and 2.2 percent in those with a population of between 50,000 and 100,000, while it gained 1.5 percent in cities with over 100,000 inhabitants.

\section{Milan and Naples: More in Common Than Just the Results?}

Let us now look more closely at what happened in the elections in the two symbolically most salient cities, Milan and Naples. In Milan, where the center-right had maintained its pre-eminence in the 2010 regional elections, the alliance was represented by the outgoing mayor, Moratti, who had previously been a minister in Berlusconi's governments. As an incumbent mayor in a long-standing center-right stronghold, she would normally have been expected to win. In Naples, where Rosa Russo Iervolino had completed the allowed two terms as mayor and the city had hit the international headlines due to its appalling "garbage problem" (and where the PD had experienced voting irregularities in the primary elections), the chances of the centerleft maintaining power over a city that it had controlled for almost two decades seemed slim. Moreover, the center-right's clear victory in the 2010 regional elections suggested that its prospects of taking the mayoralty were good. Milan and Naples were thus very different situations, but each had an easily foreseeable electoral outcome: a victory for the center-right.

Following Pisapia's victory in the center-left primaries, it appeared that a pattern had been reproduced in Milan whereby an "extreme" candidate wins the primaries but is then unlikely to gain the necessary 
support outside his or her own coalition required for victory, particularly within a context where-irrespective of who the candidate was-the center-left appeared to be in difficulty at the outset. As he was aware of this risk, Pisapia had from the very start of the election campaign underlined the non-divisive nature of his candidacy, emphasizing the fact that he was standing as the representative of a coalition; reminding people about his own professional background, which was typical of the Milanese middle classes; and choosing orange as his color to symbolize a break with traditional party colors. Moreover, the electoral campaign led by the incumbent Moratti had turned out to be less easy than expected, after years of running the city with occasional infighting with her allies and a candidacy that was supported more by the ample availability of her own personal resources than by a consensus with her allies, especially the LN. The presence of alternative candidates to the two frontrunners, furthermore, reduced the chances of anyone winning in the first round. If a second ballot were required, Moratti would need to try to win back the votes cast for the centrist Manfredi Palmeri, while Pisapia would need to do likewise with the votes cast for the M5S candidate Mattia Calise. ${ }^{15}$

Both Moratti and Pisapia ran well-organized but somewhat uninspiring campaigns to mobilize support. ${ }^{16}$ Or, rather, this was the case until 11 May, four days from the vote, when at the end of a head-tohead debate in the Sky TG24 studio, Moratti accused her rival of having taken part in a car theft during the 1970s. The aim of this revelation, which was clearly premeditated, was to take votes from the third pole by destroying Pisapia's credibility as a moderate candidate. However, Pisapia responded firmly, refusing to shake his adversary's hand (since he considered that she was using unfair tactics), but continuing to speak in the controlled manner that had characterized his campaign. While the election campaign in Milan had been fairly low-key until that point, from then on it became an almost perfect example of the familiar "modern campaign versus postmodern campaign." 17 The mayor's accusation brought criticism even from journalists who were very close to the center-right, as it risked taking attention away from the charge that Pisapia represented "communism with a legal face" and that he would be prepared to allow "a new mosque, gypsy camps, a register for cohabiting couples and for gays, places for shooting up and the legalization of drugs." ${ }^{18}$ For their part, Pisapia's supporters seized upon and satirized the accusation made against him: most notably, they sent out tweets with the hashtag \#Morattiquotes, accusing the center-left candidate of the most improbable misdemeanors, thereby building up an easy-going, reassuring opinion climate that was to help propel Pisapia into the lead in the first round and see him defeat Moratti in the second. 
One of the new (i.e., postmodern) elements in the campaign was the fact that Pisapia's staff did not attempt to coordinate these moves using the traditional top-down approach. Instead, they allowed their supporters to act spontaneously, so that their ideas could spread and multiply almost virus-like in an uncontrolled horizontal fashion, but with the potential to grab the attention also of the traditional media. ${ }^{19}$ Between the two rounds of voting, Pisapia's supporters used the Web as a hub to emphasize the difficulties of Moratti's team. Moratti herself, drawn into this computer-based frenzy, even responded on Twitter to a user who was complaining about the possible building of a mosque in the imaginary district of Sucate (a vulgar term in Milanese dialect), receiving howls of derision. This in turn helped to reinforce Pisapia's image as the moderate, calm candidate.

The campaign in Naples was markedly different. As some scholars have argued, ${ }^{20}$ Neapolitan politics in the Second Republic can in many ways be read as an example of "branding politics," in which personal leadership and the quest for direct contact with the citizenry have compensated for the weakening of the parties and the shrinking of patronage resources. Once the primaries were declared null and void, the center-left chose the ex-prefect Morcone as its candidate, while the center-right selected the entrepreneur Lettieri. The surprise element in the Neapolitan election, however, was de Magistris, an ex-magistrate and member of the IdV who had decided to stand against the two main groups, partly as a protest against the mess that the center-left had made of the primaries.

Research carried out on the election campaign has revealed the clear predominance of the candidates for the office of mayor, with very little evidence of the "micro-personalization" effect of city council chamber candidates. During the first few weeks of the campaign, de Magistris did not feature very much in the media because he was considered not only a candidate that was unworthy of support but also one that had no chance of winning. One of the main reasons for the rising support he gained during the campaign was the clear perception on the part of the electorate that he was an outsider as regards the political behavior of the main parties. The vote had appeared to be strongly personalized in the previous elections, with a personalization index ${ }^{21}$ of 1.27 for former mayor Antonio Bassolino in 1993 (declining to 1.12 in 1997) and 1.20 for Iervolino in 2001. For de Magistris, however, this figure rose to a huge 1.87 , that is, 128,303 personal votes, almost twice as many as the 68,522 obtained by the council chamber election lists that supported him. This result gave him 27.5 percent of the votes and a run-off with Lettieri (38.5 percent), while Morcone (19.2 percent) failed to make the cut. ${ }^{22}$ With 11 percentage points to make up between 
the first and second round, de Magistris ran a fairly uncompromising campaign, standing firm even against potential allies and appealing to all Neapolitan citizens "whether of the right or of the left" to cast their votes (and thus to choose a new city government) in a way that would demonstrate a clear break from previous administrations.

The first round also threw up some surprises in Milan. Studies on voter turnout show that the elections mobilized citizens, resulting in a fall in abstentions compared to previously. It was Pisapia who gained most from this, although he drew a significant number of votes from two different parts of the electorate. On the one hand, he got support from voters who had backed the center-right (particularly the LN) in 2010, while on the other (and even in the first round), he received support from those who had voted for the M5S. ${ }^{23}$ This was a sign that the electorate of the M5S was less "alternative" compared to the main coalitions than could be assumed from the statements made by its leader, Grillo.

The second round brought more surprises, but with different complexions, as shown by research carried out on voting patterns and flows. ${ }^{24}$ In Naples, de Magistris gained the votes of Morcone's voters and of other excluded candidates. However, he also took a sizable slice of Lettieri's first-round voters. Lettieri in turn paid a heavy price in terms of abstentions. In Milan, however, the turnout for the second round was even higher than for the first, thanks to the return of center-left voters who could sense victory and to the mobilization of the electorate caused by the attention focused on the election by national politicians and media in the weeks preceding the second round.

\section{The Path toward the Next General Election}

As mentioned earlier, the local elections are important not only because they determine the choice of mayors, but also because they can provide indications for-and generate reactions in the run up to-future general elections. In this sense, the 1993 local elections had largely seen the parties of the First Republic still involved, but they had also opened up the moderate political ground for Berlusconi subsequently to occupy. The 1999 mayoralty vote in Bologna had represented at a local level the "perfect defeat" for the center-left, but it had also marked the beginning of the national cycle that was to lead to Berlusconi's general election victory in 2001. The 2005 regional elections had been known as "the 12 to 2 " for the center-left, but they also ushered in the start of a period of internal struggles that were to lead to its extremely narrow general election win in $2006 .{ }^{25}$ 
From the 2011 vote, we know that, due to the defeat in Milan and the failure to capture Naples, the clear loser was the center-right and the coalition that was then in power at the national level. In a deteriorating climate of public opinion due to the economic crisis, Berlusconi's personal loss of credibility, and the increasing difficulties he was facing in holding together the coalition that had won the 2008 general election, the center-right candidates were presented with a very tough job, even where, as was the case in Naples, the center-left had long held power.

It is time now to return to the opening question of this chapter: who were the winners of this election? Mario Rodriguez has suggested that we consider the primaries among the major winners, as they created the conditions in Milan (and elsewhere) for the cohesion of the composite party alliances that supported center-left candidates. ${ }^{26}$ Particularly in the case of those candidates from other parties within the coalition, victory in the primaries brought levels of exposure (and of electoral trust, first and foremost with PD voters) that were previously unimaginable if we consider only the support from the original party. For the PD, the primaries provided a higher probability of victory for candidates from the coalition in which it played a pivotal role. Nevertheless, this had also occasionally brought heavy defeats and consequently the need to play down its central position when supporting candidates from parties that had allied with it. The third pole should also be counted as one of the victors, as on a number of occasions it proved capable of holding the balance of power for the outcome of the contest. According to the sociologist Luca Ricolfi, the so-called Santoro party-made up of the most explicit and extreme "anti-Berlusconi" political actors, that is, the SEL, IdV, and M5S - was the real winner of the 2011 elections. ${ }^{27}$ Other commentators such as Diamanti have, however, pointed to a change in public opinion as one of the main common elements in the vote. This "mild shift" (with the unusual exception of Naples), which was wellrepresented by the PD (the linchpin for the winning alliances), was aimed at reducing the power of divisive politics. ${ }^{28}$

The 2011 round of local elections was a historic one. And it was most certainly so in Milan. This was not only due to the outcome, but also because it produced some unexpected features: the use of primaries by Pisapia to consolidate the coalition and the attack made by the incumbent Moratti to which Pisapia responded with moderation and thereby succeeded in strengthening his own reassuring image (which was also reinforced by the center-left campaign through various forms of social media).

The picture becomes more complicated, however, if we attempt to find indications regarding the possible outcome of the next general election. The 2011 elections, if we follow Diamanti's interpretation, saw the 
crumbling of political myths that have characterized Italian politics in recent years, the first of which was the "defeatism" of the center-left in the presence of an "invincible" Berlusconi. ${ }^{29}$ Nonetheless, the fragmentation and the variety of the offer, the abstentionism, and the regional variations in the results remind us that the success of the center-left should not be taken as a preview of the next general election. The center-right, which held power at the national level and whose leader was in the midst of a popularity crisis, lost the local elections butdespite these factors-captured 19 large councils (out of 133) from the center-left. This confirms that even when there is a clear political result in a local election, there is also a mosaic effect that depends on local choices and circumstances: outgoing mayors usually set out with an advantage, just as parties in central government typically pay a local price for decisions made nationally. Voters, however, also choose from the political offers that they are presented with in their own cities. This has certainly been the case in previous years, when the voters (even center-right ones) were unimpressed by attempts to "nationalize" the issues for the local elections. ${ }^{30}$

A differentiated offer and specific local issues (particularly in the first round), along with regional variations, are nothing new. It is therefore worth adding a note of caution when generalizing about the most immediately obvious features of the 2011 elections. In Milan, the center-left and Pisapia won on a high turnout, and in Turin as well the turnout remained steady. But in the rest of the North it declined, and this seems to have affected the center-right more than the center-left, just as happened in 2005 before Berlusconi succeeded, at the subsequent 2006 general election, in mobilizing an extraordinary degree of support that was to put him within a whisker of turning the predicted easy center-left victory upside down.

If we add to this the possibility of electoral system reforms, the redefinition of the political offer and the leadership of the parties and coalitions, the timing, and the special characteristics of the next general election campaign (including the resources available to competing candidates), it is clear that there are more unknown factors than certainties on the path toward the next general election. Compounding these uncertainties are the regional variations in voting in Italy. Finally, when considering the post-second-round picture of centerright defeat in 2011, it is also worth remembering that the first round of voting produced a far more nuanced verdict than the second, notwithstanding the images that may stick in our minds of Piazza Duomo festooned in orange, however significant those images may have been. 


\section{Notes}

1. A. Di Virgilio, "Elezioni locali e destrutturazione partitica: La nuova legge alla prova," Rivista Italiana di Scienza Politica, no. 1 (1994): 107-165.

2. The Madonnina is the statue on top of the Duomo in Milan.

3. P. Feltrin and P. Natale, "Competizione elettorale, sondaggi e clima d'opinione," in Nel segreto dell'urna: Un'analisi delle elezioni politiche del 2006, ed. P. Feltrin, P. Natale, and L. Ricolfi (Turin: UTET, 2007), 87-108.

4. For the list and the results, please consult the documentary appendix (likewise for the vote in the 11 provinces). In the data that follow, there will be 30 rather than 31 provincial capitals. Villacidro (Provincia del Medio Campidano) is excluded from the analysis since it is governed by a single-round electoral system that applies to cities with fewer than 15,000 inhabitants and has a political offer made up exclusively of civic lists. In cities with over 15,000 inhabitants, the electoral law for councils allows candidacies for the mayorship linked to coalition lists. In those with populations of less than 15,000, however, each candidate may be supported by only one list, with the effect that there are more civic lists not linked to parties.

5. R. D’Alimonte, “Il centro-sinistra vince ma i due poli perdono," Il Sole 24 Ore, 5 June 2011.

6. When assessing the political offer, it should be remembered that not all parties are present in equal measure with their symbol across the national territory. This can happen because lack of support may prevent their access to the council or because they are encompassed within civic lists or are allied with them. In table 4.1 we have therefore hypothesized that-in the absence of official lists - the FLI and UdC have formed a third pole; the PdL and LN have formed an alliance on the center-right; and the PD, SEL, and IdV have formed one on the center-left. For details on individual cases, please refer to the documentary appendix.

7. A study carried out by D'Alimonte on the number of lists has shown that while the center-right area remained stable (around six lists) and on the center-left there was a reduction (from eight to just under six), the "others" almost doubled from an average of five to more than nine lists. See R. D’Alimonte, "Exploit di liste: Per ora vince la frammentazione," Il Sole 24 Ore, 12 May 2011.

8. G. Legnante, "The Elections in the Cities: Yet Another Defeat for the Center-Right," in Italian Politics: Quo Vadis? ed. C. Guarnieri and J. Newell (New York: Berghahn, 2005), 65-82.

9. L. De Sio and G. Legnante, "Economic Crisis and European Elections: An Alteration of the Electoral Cycle?" Quaderni di Scienza Politica, no. 3 (2010): 447-489; P. Feltrin and P. Natale, "Le elezioni regionali 2010 in Italia: Le molte conferme e le novità inattese," Polena, no. 1 (2010): 124-147.

10. P. Bellucci and V. Memoli, "Insuccessi del governo, paura delle tasse," in Dov'è la vittoria? Il voto del 2006 raccontato dagli italiani, ed. P. Bellucci and P. Segatti (Bologna: Il Mulino, 2006), 209-224. 
11. P. Natale, “Congiuntura politica,” Polena, no. 2 (2011): 123-126; P. Natale, “Pisapia, miracolo a Milano?” Europa, 1 April 2011; P. Natale, "Il 15 maggio, il Pdl rischia,” Europa, 29 April 2011.

12. The case of Olbia was unusual as it changed political color but not its mayor. Gianni Giovannelli, elected in 2007 with the center-right, was the winning candidate for the center-left in 2011.

13. I. Diamanti, "Se tramonta il mito del Nord padano," La Repubblica, 1 June 2011.

14. R. D’Alimonte, "Il centro-sinistra vince ma i due poli perdono," Il Sole 24 Ore, 5 June 2011.

15. P. Natale, "Pisapia, miracolo a Milano?"

16. M. Cacciotto, "Moratti, Pisapia, Palmeri: Perché nessuno dei tre candidati a Milano ha trovato lo slogan giusto,” Il Sole 24 Ore, 8 April 2011; M. Rodriguez, “Un frame per la nuova Milano,” Europa, 20 April 2011.

17. J. Blumler and D. Kavanagh, "The Third Age of Political Communication: Influences and Features," Political Communication, no. 3 (1999): 209-230.

18. M. Belpietro, “La Moratti accusa Pisapia: E gli fa un favore,” Libero, 12 May 2011.

19. P. Bottazzini, “Dati alla mano la sinistra stavolta ha capito la Rete,” http:// www.linkiesta.it/dati-alla-mano-la-sinistra-stavolta-ha-capito-la-rete.

20. E. Pasotti, Political Branding in Cities (Cambridge: Cambridge University Press, 2010.

21. The personalization index is based on the relationship between the votes obtained by each candidate and the total of votes obtained by the lists supporting them. When the personal consensus is equal to its potential "base," therefore, it has a value of 1 , and it goes up as the personal votes gained by the candidate increase. Cf. G. Baldini and G. Legnante, Città al voto: I sindaci e le elezioni comunali (Bologna: Il Mulino, 2000).

22. See F. Amoreti and F. Musella, "Il voto a Napoli: Una nuova stagione (anti)politica?" paper presented at the 25th Conference of the Italian Society of Political Science, Palermo, 8-10 September 2011.

23. P. Natale, “Anche i leghisti votano Pisapia,” Europa, 25 May 2011.

24. L. De Sio, "I flussi di voto nel ballottaggio di Napoli: De Magistris prende voti a tutti, anche a Lettieri" and "I flussi di voto nel ballottaggio di Milano: Una forte polarizzazione politica,” http://cise.luiss.it; Istituto Cattaneo, "I flussi elettorali a Napoli fra le elezioni I e II turno delle comunali 2011" and "I flussi elettorali a Milano fra le elezioni I e II turno delle comunali 2011," http://www.cattaneo.org.

25. Di Virgilio, "Elezioni locali e destrutturazione partitica: La nuova legge alla prova”; G. Baldini, P. Corbetta, and S. Vassallo, La sconfitta inattesa: Come e perché la sinistra ha perso a Bologna (Bologna; Il Mulino, 2000); S. Vassallo, "The Regional Elections: Winning Too Convincingly?" in Italian Politics: The End of the Berlusconi Era? ed. G. Aymot and L. Verzichelli (New York: Berghahn, 2006), 47-66.

26. M. Rodriguez, "Hanno vinto le primarie,” Europa, 3 June 2011; G. Ferrara, "Il ricostituente delle primarie," Il Giornale, 5 June 2011; R. D’Alimonte, 
"Primarie Pdl, antidoto a correnti e carisma appannato del leader," Il Sole 24 Ore, 4 June 2011.

27. L. Ricolfi, "Il vincitore nascosto delle elezioni,” La Stampa, 1 June 2011.

28. I. Diamanti, "La svolta mite del paese stanco di urla," La Repubblica, 6 June 2011.

29. I. Diamanti, "Perché è cambiato il clima di opinione," La Repubblica, 30 May 2011.

30. G. Legnante, "The 2003 Local Elections: First Local and Then National Defeats for the Casa della Libertà,” in Italian Politics: Italy between Europeanization and Domestic Politics, ed. V. Della Sala and S. Fabbrini (New York: Berghahn, 2004), 63-79. 